\title{
Assessing energy use and overheating risk in net zero energy dwellings in UK
}

Rajat Gupta* and Matt Gregg

Low Carbon Building Group, Oxford Institute for Sustainable Development, School of Architecture, Oxford Brookes University, Oxford, OX3 OBP, UK

*rgupta@brookes.ac.uk

\begin{abstract}
This paper presents the methodological approach and findings of a simulation study of advanced energy conservation, generation and management technologies applied to two case study dwellings in the UK, so as to achieve net zero energy (NZE) target that includes a reduction of net regulated energy (HVAC) to $0 \mathrm{kWh} / \mathrm{m}^{2}$ per year and energy generation of at least $50 \mathrm{kWh} / \mathrm{m}^{2}$ per year. The performance of the dwellings are also tested for a change in energy use and risk of summertime overheating in future climates in the short (2030s), medium (2050s) and long term (2080s).

The findings indicate that to meet the NZE targets, regulated loads need to reduce by about half (over current Building Regulations) with community (rather than building-level) renewables playing a major role. It is also found that the NZE targets, given current regulations, are not particularly difficult to achieve in design with regard to energy efficiency but are highly expectant with regard to renewable energy. Further, summertime overheating is projected to be a risk for net zero energy dwellings by the 2050s. Despite this the regulated energy use of both dwellings is projected to reduce by $11 \mathrm{kWh} / \mathrm{m}^{2} / \mathrm{yr}$, accompanied by a small increase in renewable generation ( $2 \mathrm{kWh} / \mathrm{m}^{2} / \mathrm{yr}$ ).
\end{abstract}

\section{Keywords}

Energy efficiency, net zero energy building, simulation, climate adaptation, overheating 


\section{Introduction}

Buildings are central to both UK and EU energy efficiency policy. Improving the energy performance of the UK's building stock is crucial, not only to achieve the EU's 2020 targets but also to meet the UK's longer term climate change target of $80 \% \mathrm{CO}_{2}$ emission reduction by 2050 . The European Commission [1] outlines three specific targets to be met by 2020 (relative to 1990 levels): reduce greenhouse gas emissions (GHG) by $20 \%$, increase energy efficiency by $20 \%$, and increase contribution from renewable energy sources equivalent to $20 \%$ of final energy consumption.

A key element of the Energy Performance in Buildings Directive (EPBD) recast (Directive 2010/31/EU) is its requirements regarding nearly zero-energy building, which is defined as "a building that has very high energy performance..." and its nearly zero or very low amount of energy demand is provided by renewable energy systems, which are either on-site or nearby [2]. Directive 2010/31/EU Article 9 requires that member states shall ensure that by 31 December 2020 all new buildings are nearly zero-energy buildings; and after 31 December 2018, new buildings occupied and owned by public authorities are nearly zero-energy. The EPBD nearly zero energy building definition, as described in Article 2, constitutes a 'broad' definition. The Directive lays down the end-results that must be achieved by every Member State. National authorities have to adapt their laws to meet these goals, but are free to decide how to do so [2].

In the context of implementing these standards for new low energy homes in the UK, this paper presents the methodology and findings from a systematic dynamic thermal simulation study of advanced energy conservation, generation and management technologies applied to two case study dwellings in the UK, so as to achieve a net zero energy (NZE) target. A net zero energy building, in contrast to nearly zero energy, produces enough renewable energy to cover its annual energy consumption [3]. To ensure that design is futureproof, the performance of the dwellings are then tested for change in energy and overheating risk in future climates (2030s, 2050s and 2080s) given that mean external temperatures and solar insolation are expected to increase with a warming climate [4]. This study is part of a Horizon 2020 research project with case studies in Cyprus, France, Italy and the UK, on design, optimisation, implementation and monitoring of advanced and costeffective solutions for achieving NZE and positive energy dwellings. This paper focusses on the results of the modelling and simulation of two case study dwellings (part of a housing development) in the UK so as to satisfy the Directive, by meeting the following NZE targets:

- To achieve a net regulated energy of $\leq 0 \mathrm{kWh} / \mathrm{m}^{2}$ per year. The reduced energy consumption will be attained through the application of a number of innovative energy technologies.

- In order to achieve the NZE target above, at least $50 \mathrm{kWh} / \mathrm{m}^{2}$ renewable energy per year must be generated, on average, in the case study development through either building integrated and/or community renewable energy systems.

\section{NZE dwellings and summertime overheating}

For over twenty years, NZE buildings have been successfully demonstrated in many countries, including Austria, Egypt, Germany, the UK, and the USA [3]. These buildings have explored exemplar use of miniature cogeneration, high efficiency heat pumps, PV and passive measures like superinsulation, highly reflective surfaces, seasonal pre-conditioning of incoming air via buried pipe. 
Research on the subject of NZE buildings has developed significantly to assist in efficient design, efficient monitoring and operation; however the benefit reaches beyond to all buildings whether they are designed to be NZE or not [3]. Until about 15 years ago NZE dwellings were single dwellings built by pioneering developers and architects $[5,6]$, i.e., the NZE drive has largely been focussed on the individual building [7]; however, shared-effort, i.e. dwellings sharing renewable technology to cover energy consumption, has advantages in terms of initial investment costs and energy management [8]. Generally, a set of dwellings, neighbourhoods or communities can support certain technologies for heating, cooling, and electricity generation more cost-effectively through economy of scale. As an example, combined heat and power (CHP) systems are more efficient when a large number of dwellings have to be served. Beyond the typical domestic neighbourhood, mixed-use communities benefit from a mix of occupancies and uses, which can support more efficient use of infrastructure, more space for renewable systems, and more efficient use of energy wherein almost 24-hour consumption maximises the use of district heating and power sources [9]. The community level approach is also helpful in achieving an overall cumulative NZE balance where not all buildings are able to meet the NZE target due to individual limitations [10].

Although NZE dwellings are designed to reduce heat losses through improved airtightness and increased insulation, this can potentially raise the risk of overheating and inadequate ventilation [11]. Overheating can occur in such dwellings as a result of a number of causes acting alone or in combination. These can include heat gain from high external temperatures, direct solar gain on the exterior surface or penetrating glazing, and internal heat gains. Home characteristics such as dark surface materials, rooms in the roof, skylights, inability to ventilate due to location, predominately dark hard surface surroundings, single aspect flats on upper floors, and orientation that allows late solar gain in windows can all contribute to overheating [12].

Much research has set out to establish the risk of overheating by simulating the current and future risk in older dwellings [13] and in newer high-performing dwellings [14, 15]. A number of studies have also demonstrated present-day monitored overheating or summer 'discomfort' in existing dwellings and newly built dwellings [16] in the UK, and abroad, in Denmark [17], Sweden [18] and Estonia [19]. Within these studies the propensity to overheat is much greater in newer dwellings, e.g. passivhaus designed dwellings, and particularly in flats. It is important to note that overheating is defined slightly differently from region to region, however, there is roughly an agreement that surpassing hours at $26-27^{\circ} \mathrm{C}$ is problematic.

A number of studies link overheating in well-insulated buildings with highly important factors being solar radiation $[12,15,17,20]$ and ventilation rate $[12,20,21]$. In response, highly effective adaptive responses include the following.

- Shading $[12,22]$, where the purpose is to limit or exclude incident solar gain on building fabric or entering through glazing. The effectiveness of shading is in design, considering orientation and seasonal changes, and it can be highly flexible; shading can be fixed, manually controlled or automated.

- High albedo surfacing [12] of walls and roofs can reduce the heat gain and retention from incident solar radiation; a method commonly used in warmer climates. High albedo surfaces can also be considered for surrounding hardscaped surfaces to further contribute to reduction of the urban heat island effect.

- Night-time ventilation [15, 21, 23] particularly as cross-ventilation [24], where appropriate (lower temperatures and relative humidity), can also be effective in releasing excess heat 
that is built up and stored in the dwelling during the day. Where night-time ventilation by window opening, shown to be highly effective in cooling the spaces in northern climates, is problematic due to insect, noise, or driving rain, increased mechanical ventilation has been shown to be slightly less effective, albeit acceptable compromise [15].

Though modelling exists to establish effective adaptive responses to the impact of future climate on high-performing / Passivhaus / NZE dwellings, it is also useful to consider findings from research of dwellings built to be high-performing in southern / warmer-climates. In one such study with multiple analogue examples for the UK's future climate(s), Schnieders [25] concludes that the Passivhaus concept is able to provide a comfortable indoor climate, in accordance with EN/ISO 7730 in all twelve locations (including southern Germany, Italy, etc.) exclusively by pre-conditioning with active cooling the supply airflow. It is further explained that external shading in summer, reduction of solar load through opaque elements and minimising internal heat loads are important measures in maintaining thermal comfort. This study uses a simulation based approach to achieve the NZE targets for two dwellings and also examine the risk of summer time overheating in the dwellings, under current and future climates.

\section{Methods}

Using the well-established suite of Integrated Environmental Solution's Virtual Environment (IES VE) simulation software (dynamic thermal simulation) that include ModellT, Apache, MacroFlo and VistaPro, the expected energy performance of the dwellings and overheating potential are simulated. For comparative purposes five variations of the energy models are created as follows:

1. Baseline: the as-designed model;

2. Reference cases: reverse modelling of the baseline to establish reference cases:

a. Typical reference case, i.e. consumption of typical existing dwelling in England,

b. UK building regulations reference case: applied building regulations to the model;

3. Baseline+: an improved version of the Baseline model to further reduce consumption though established measures;

4. NZE reduction \& generation (NZE_red+gen): a model that combines the technologies to be tested in the project with the Baseline+ model; and

5. NZE building energy management systems (NZE_BEMS): to further explore reduction, the influence of a BEMS is simulated to evaluate the potential for further reduction of regulated and un-regulated loads (e.g. lighting).

The following steps are undertaken to reach the NZE targets set out in the introduction: (1) Assessing and establishing the baseline energy performance of the two dwellings (2) Reducing the regulated energy consumption to or below $50 \mathrm{kWh} / \mathrm{m}^{2}$ (3) and generating at least $50 \mathrm{kWh} / \mathrm{m}^{2}$ of electricity from building level and community level renewables.

The NZE targets are focussed on regulated energy consumption covering the end uses of space heating, cooling, ventilation, domestic hot water, fans and pumps, while unregulated loads such as lighting, computers, televisions and cooking are not included. Net regulated energy is calculated as below:

- Regulated energy $=$ space heating + cooling + ventilation + domestic hot water $(D H W)+$ fans + pumps 
- $\quad$ Renewable energy $(R E)=$ Energy production from building level and community renewables.

- Net regulated energy $=($ Regulated energy $)-(R E)$

Future climate change projections are simulated on the final NZE model (model 5) to assess the potential future change in energy targets and the magnitude of the risk of overheating in the dwellings. Weather files are obtained from a catalogue of current and future weather files developed by the PROMETHEUS project [26]. The following simulation runs are made for assessing the risk of overheating:

1. Current conditions - baseline weather years (test reference year (TRY));

2. 2030s climate period, high emissions $(H), 50 \%$ probability (design summer year (DSY);

3. 2050s climate period, high emissions, $50 \%$ probability (DSY); and

4. 2080 s climate period, high emissions, $50 \%$ probability (DSY).

The overheating assessment follows the Adaptive Methods Approach as outlined in: The limits of thermal comfort: avoiding overheating in European Buildings, Technical Memorandum 52 (CIBSE TM52) [27]. The adaptive method is a dynamic threshold based on changes in external temperature which also includes levels of occupant sensitivity. According to this method, comfortable temperatures are based on adaptation to external temperatures during the preceding few days, i.e. the running mean. The assessment considers the level of thermal expectation recommended for the occupants. New dwellings are assessed using Category II -Normal expectation (for new buildings and renovations). Three criterion of the adaptive comfort method provide a robust and balanced assessment. If two or more of these criteria were met, the room is deemed to have overheated:

- Criterion 1: hours of exceedance: The number of hours during which $\Delta T$ is greater than or equal to one degree $(K)$ during the recommended period May to September (or available period) inclusive shall not be more than 3 per cent of occupied hours.

- Criterion 2: daily weighted exceedance $\left(W_{e}\right)$ : the time (hours and part hours) during which the operative temperature exceeds the specified range during the occupied hours, weighted by a factor that is a function depending on by how many degrees the range has been exceeded. We shall be $\leq 6$ hours in any one day.

- Criterion 3: upper limit temperature: the absolute maximum value for the indoor operative temperature: $\Delta \mathrm{T}$ shall not exceed $4 \mathrm{~K}$.

Other modelling assumptions made for overheating simulation include the following:

- Activity level: 90 metabolic rate (met)

- Clothing level: 0.69 clothing insulation (clo)

- Mean radiant temperature, external temperature, air speed, relative humidity and occupancy are from the weather files and the model respectively.

\section{Characteristics of the case study dwellings}

The case study dwellings are a part of a new development being built by a leading housing association in York, England. The development features a wide range of different dwelling sizes and forms, all served by a gas boiler district heating system located in an on-site energy centre. All the dwellings have been designed to a fabric first approach, to ensure that heat loss is kept to a 
minimum through good thermal insulation, and good levels of air tightness. To represent common dwelling types, a semi-detached and a detached dwelling were selected as case studies, both have northeast facing facades. The two case study dwellings will be built in autumn 2017.

- Dwelling $\mathbf{A}$ is a two bed semi-detached with $84.4 \mathrm{~m}^{2}$ area;

- Dwelling B is a three bed detached with $129.6 \mathrm{~m}^{2}$

Figure 1 shows the form of the dwellings as modelled in IES.
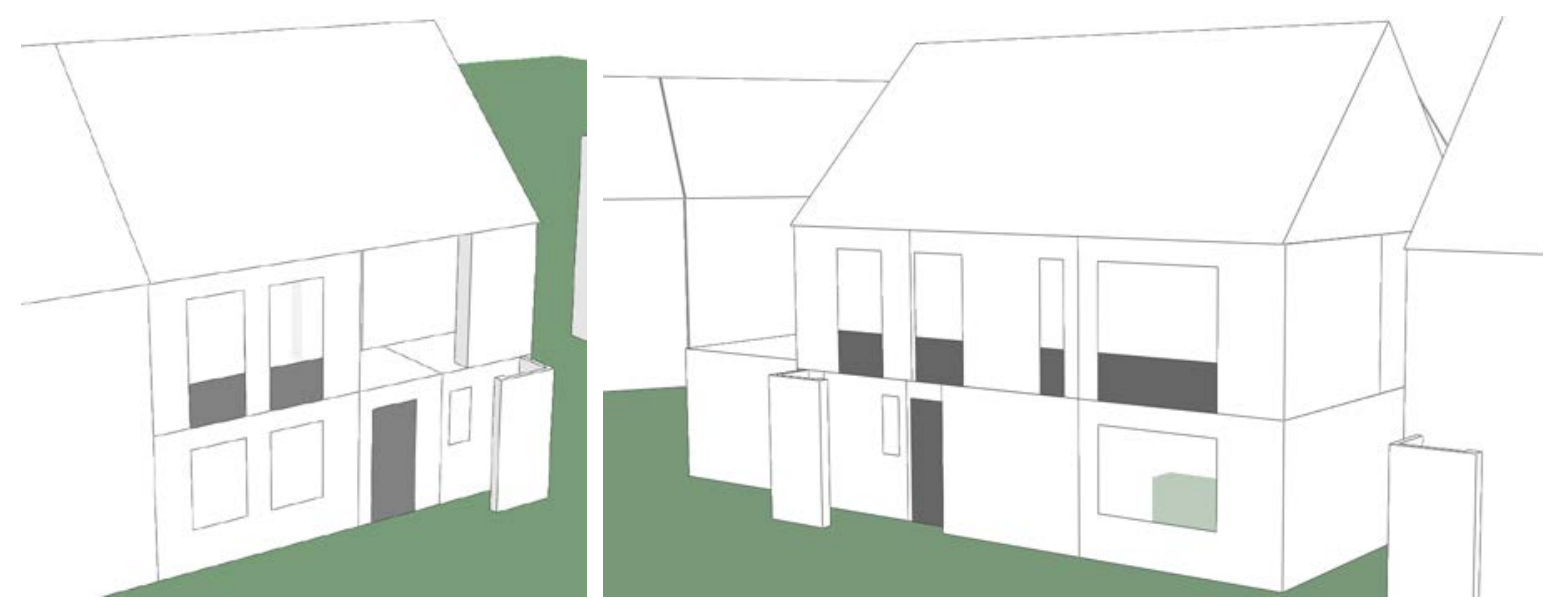

Figure 1 Dwelling A (left); Dwelling B (right)

Table 1 indicates built details for the baseline dwellings. The baseline dwellings were originally designed to satisfy Code for sustainable Homes iLevel 4. Fabric U-values, occupancy (three occupants per dwellings), domestic hot water (DHW) consumption, and gains were detailed in the UK's Standard Assessment Procedure (SAP) documents provided by the architect. Operational profiles for occupancy used in the model are those developed by the UK National Calculation Methodology (NCM). The profiles were also used to define DHW, lighting and appliance use.

Table 1 Characteristics of the case study dwellings for the building energy model

\begin{tabular}{|l|l|l|}
\hline Building element & Type & Final design parameter \\
\hline External wall U-value & Filled cavity wall & $0.17 \mathrm{~W} /\left(\mathrm{m}^{2} . \mathrm{K}\right)$ \\
\hline Roof U-value & Pitched w/ 185mm insulation & $0.15 \mathrm{~W} /\left(\mathrm{m}^{2} . \mathrm{K}\right)$ \\
\hline Ground floor U-value & Solid & $0.15 \mathrm{~W} /\left(\mathrm{m}^{2} . \mathrm{K}\right)$ \\
\hline Window U-value & \multirow{2}{*}{ Double glazed in uPVC frame } & $1.3 \mathrm{~W} /\left(\mathrm{m}^{2} . \mathrm{K}\right)$ \\
\cline { 2 - 3 } Window g-value & & 0.4 \\
\hline Door U-value & Insulated & $1.4 \mathrm{~W} /\left(\mathrm{m}^{2} . \mathrm{K}\right)$ \\
\hline $\begin{array}{l}\text { Design air } \\
\text { permeability }\end{array}$ & $6 \mathrm{~m}^{3} /\left(\mathrm{h} \cdot \mathrm{m}^{2}\right) @ 50 \mathrm{pa}$ & \\
\hline Heating & Gas boiler - district heat (eff. 0.876$)$ & \\
\cline { 2 - 3 } & Set points: Living: $21^{\circ} \mathrm{C}$; all others $18^{\circ} \mathrm{C}$ \\
\hline $\begin{array}{l}\text { Mechanical } \\
\text { ventilation }\end{array}$ & MEV: Extract only: Kitchen $60 \mathrm{l} / \mathrm{s} ;$ bathrooms $15 \mathrm{I} / \mathrm{s}$ \\
\hline
\end{tabular}




\begin{tabular}{|l|l|}
\hline DHW & 103 L/day \\
\hline Heating schedule & $\begin{array}{l}\text { Weekday: 07:00 - 9:00 \& 16:00 - 23:00 } \\
\text { Weekend and holidays: 07:00 - 23:00 } \\
\text { Annually: 15 October - 15 May }\end{array}$ \\
\hline Occupancy schedule & $\begin{array}{l}\text { Bedroom: 22:30 - 06:30 } \\
\text { Living room: 06:30 - 9:30 \& 18:00 - 22:30 }\end{array}$ \\
\hline $\begin{array}{l}\text { Window opening } \\
\text { schedule }\end{array}$ & $\begin{array}{l}\text { Bedroom: 18:00 - 06:30 } \\
\text { Living room: matches occupancy (i.e. windows closed when away) } \\
\text { Annually: 1 June - 30 September (period assessed for overheating) }\end{array}$ \\
\hline
\end{tabular}

Beyond the baseline, the Baseline+ version of the models employed an air permeability of 4 $\mathrm{m}^{3} /\left(\mathrm{h} . \mathrm{m}^{2}\right) @ 50 \mathrm{pa} ; 2 \mathrm{~kW}$ photovoltaic (PV) system; a $4 \mathrm{~m}^{2}$ solar thermal system; and high efficiency lighting and appliances. No fabric changes, aside from improvement in air permeability were made at this point.

To define the reference building according to typical existing domestic stock in England (Reference Typ.), the most common age group for semi-detached dwellings was selected: 1945-1964 [28]. Typical reference case construction details were obtained from the Tabula \& Episcope Building Typology Brochure [29] but were updated based on the following facts [28]:

- $68 \%$ of cavity wall dwellings were estimated to have cavity wall insulation by 2013 ,

- $80 \%$ of all dwellings and $91 \%$ of housing association homes were estimated to have more than half of windows double-glazed by 2013,

- $56 \%$ of dwellings had $150 \mathrm{~mm}$ or more of loft insulation by 2013.

For the UK Building Regulation reference case, the current building regulations were used to model thermal design parameters [30]. Using data and guidelines from the above sources, table 2 lists the design parameters used where they differ from the baseline model.

Table 2 Model design parameters for the reference case

\begin{tabular}{|l|c|c|}
\hline \multicolumn{1}{|c|}{ Building element } & Reference typical & Reference building regulation \\
\hline External wall U-value & $0.6 \mathrm{~W} /\left(\mathrm{m}^{2} . \mathrm{K}\right)$ & $0.26 \mathrm{~W} /\left(\mathrm{m}^{2} . \mathrm{K}\right)$ \\
\hline Roof U-value & $0.24 \mathrm{~W} /\left(\mathrm{m}^{2} . \mathrm{K}\right)$ & $0.20 \mathrm{~W} /\left(\mathrm{m}^{2} . \mathrm{K}\right)$ \\
\hline Ground floor U-value & $0.59 \mathrm{~W} /\left(\mathrm{m}^{2} . \mathrm{K}\right)$ & $0.25 \mathrm{~W} /\left(\mathrm{m}^{2} \cdot \mathrm{K}\right)$ \\
\hline Window U-value & $2.2 \mathrm{~W} /\left(\mathrm{m}^{2} . \mathrm{K}\right)$ & $1.6 \mathrm{~W} /\left(\mathrm{m}^{2} . \mathrm{K}\right)$ \\
\hline Window g-value & 0.67 & 0.4 \\
\hline Door U-value & $3.0 \mathrm{~W} /\left(\mathrm{m}^{2} . \mathrm{K}\right)$ & $1.9 \mathrm{~W} /\left(\mathrm{m}^{2} \cdot \mathrm{K}\right)$ \\
\hline Design air permeability & $15-30 \mathrm{~m}^{3} /\left(\mathrm{h} \cdot \mathrm{m}^{2}\right) @ 50 \mathrm{pa}$ & $8 \mathrm{~m}^{3} /\left(\mathrm{h} \cdot \mathrm{m}^{2}\right) @ 50 \mathrm{pa}$ \\
\hline
\end{tabular}

In addition to the energy targets, the study aims to demonstrate the application of innovative energy efficiency and renewable energy generation technologies for achieving NZE targets. Table 3 summarises the technical details of the advanced energy technologies that are introduced for the 
NZE red+gen stage and are relevant to the UK climate. These include extruded polystyrene insulation with low thermal conductivity (adv. ins.), building integrated PV (biPV), a solar concentration module which provides thermal and electrical energy (for simplicity named CHP), and a combined solar and wind system (WindPV). Table 4 shows the modelling procedures used for simulating the savings from these technologies.

Table 3 Advanced energy technologies selected for the research study

\begin{tabular}{|l|l|}
\hline $\begin{array}{l}\text { Advanced Insulation } \\
\text { (building level) }\end{array}$ & $\begin{array}{l}\text { Lightweight composite cool thermal insulating extruded polystyrene for high } \\
\text { thermal resistance and high solar reflectance }\end{array}$ \\
\hline $\begin{array}{l}\text { biPV (building/ } \\
\text { community level) }\end{array}$ & $\begin{array}{l}\text { Precast, dry-assembled and pre-stressed translucent biPV components made of } \\
\text { Dye Sensitized Solar Cells integrated glass blocks - } 1 \mathrm{kWp} \text { with } 8 \% \text { conversion } \\
\text { efficiency requires almost 15-20 } \mathrm{m}^{2}\end{array}$ \\
\hline $\begin{array}{l}\text { Solar PV and thermal } \\
\text { CHP (community level) }\end{array}$ & $\begin{array}{l}\text { Optics technology (lenses or curved mirrors) is used to focus the sun's radiation on } \\
\text { a small area occupied by one or more high efficiency photovoltaic cells (up to } 44 \% \\
\text { of conversion rate) to generate electricity. Capturing the waste heat increases the } \\
\text { overall efficiency of the system and justifies the efforts to develop a CPV/T hybrid } \\
\text { technology. (Requires sun-tracking) }\end{array}$ \\
\hline $\begin{array}{l}\text { WindPV (building/ } \\
\text { community level) }\end{array}$ & $\begin{array}{l}\text { Building-based modular wind turbine system that efficiently captures wind energy } \\
\text { by exploiting the pressure differences around the building and the solar radiation } \\
\text { to generate electricity }\end{array}$ \\
\hline
\end{tabular}

Table 4 Modelling procedures for simulation of the selected advanced energy technologies

\begin{tabular}{|l|l|}
\hline $\begin{array}{l}\text { Advanced Insulation } \\
\text { (building level) }\end{array}$ & $\begin{array}{l}\text { Modelled in IES VE: additional } 20 \mathrm{~mm} \text { of insulation in external walls resulting in } \\
0.15 \mathrm{~W} /\left(\mathrm{m}^{2} . \mathrm{K}\right) ; \text { Additional } 45 \mathrm{~mm} \text { of insulation in roof resulting in } 0.12 \mathrm{~W} /\left(\mathrm{m}^{2} . \mathrm{K}\right)\end{array}$ \\
\hline biPV (building level) & $\begin{array}{l}\text { Modelled in IES VE: installed in south roof face; low-e triple glazing with dye- } \\
\text { sensitized solar cells integrated }\end{array}$ \\
\hline CHP (community level) & $\begin{array}{l}\text { Modelled in tech. provider's software: solar and thermal power are calculated } \\
\text { from solar azimuth, solar elevation (altitude), global radiation, and diffuse } \\
\text { radiation }\end{array}$ \\
\hline $\begin{array}{l}\text { WindPV (community } \\
\text { level) }\end{array}$ & $\begin{array}{l}\text { Modelled in tech. provider's software: wind and solar power are calculated from } \\
\text { wind direction, wind speed, global radiation and solar altitude }\end{array}$ \\
\hline
\end{tabular}

As a result of applying the technologies, the changes in the thermal characteristics of the NZE (NZE_red+gen) model are summarised in Table 5 . The change from cavity wall insulation to external insulation resulted in an increase of $20 \mathrm{~mm}$ of insulation material.

Table 5 NZE model characteristics (NZE_red+gen)

\begin{tabular}{|l|l|l|}
\hline Building element & Type & Final design parameter \\
\hline External wall U-value & External insulation & $0.15 \mathrm{~W} /\left(\mathrm{m}^{2} . \mathrm{K}\right)$ \\
\hline Roof U-value & Pitched $\mathrm{W} / 230 \mathrm{~mm}$ insulation & $0.12 \mathrm{~W} /\left(\mathrm{m}^{2} . \mathrm{K}\right)$ \\
\hline Ground floor U-value & Solid & $0.15 \mathrm{~W} /\left(\mathrm{m}^{2} . \mathrm{K}\right)$ \\
\hline Windows and Door & No change & \\
\hline
\end{tabular}




\begin{tabular}{|l|l|}
\hline $\begin{array}{l}\text { Design air } \\
\text { permeability }\end{array}$ & $4 \mathrm{~m}^{3} /\left(\mathrm{h} \cdot \mathrm{m}^{2}\right) @ 50 \mathrm{pa}$ \\
\hline $\begin{array}{l}\text { Heating, ventilation, } \\
\text { DHW and schedules }\end{array}$ & No change \\
\hline
\end{tabular}

\section{Simulation results}

\section{Baseline models}

The baseline dwellings were designed to perform better than the UK building regulations. The Baseline+ version improved the results a little beyond the baseline by introducing renewable energy at the building level. Figure 2 shows the results for the model for the first three modelling stages (Reference: typical and regulations; Baseline and Baseline+).

\section{Baseline models (Pre-NZE)}

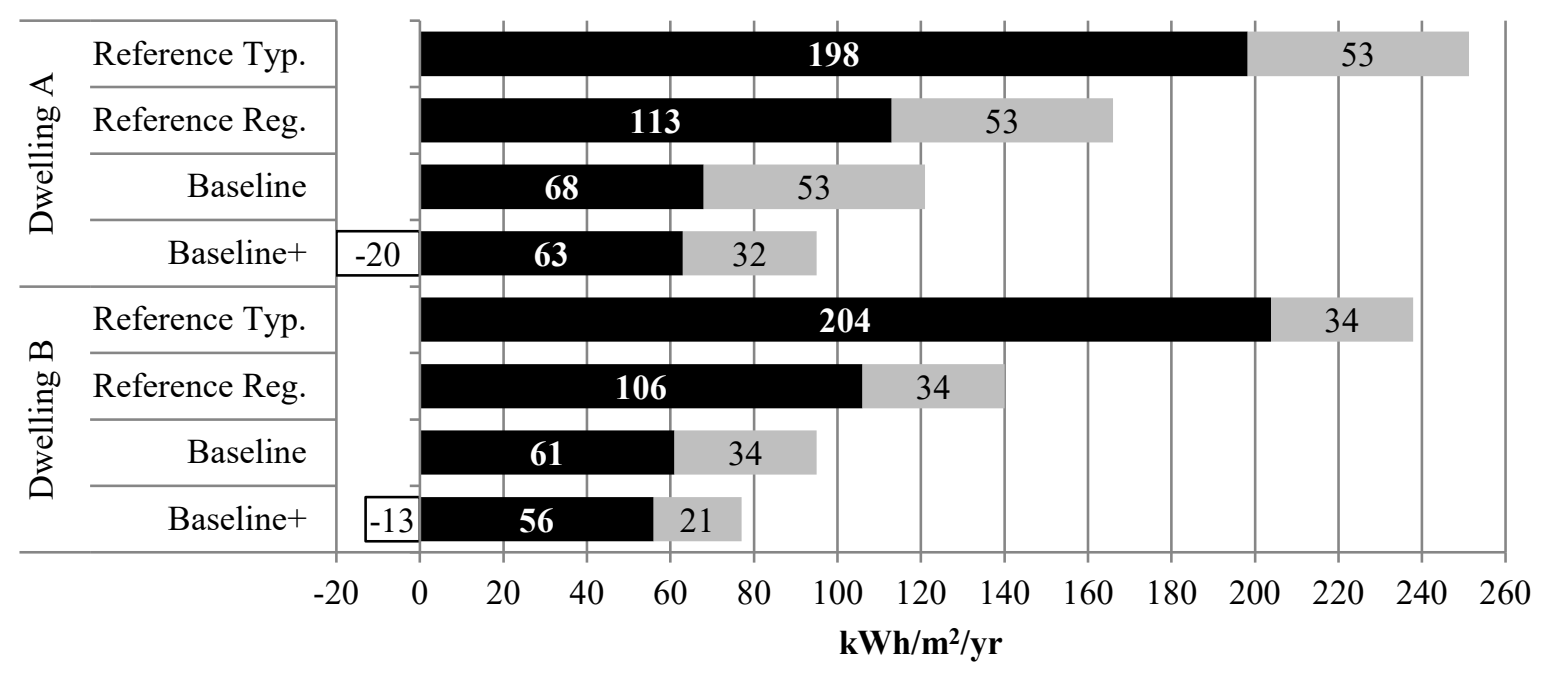

$\square$ Building integrated RE $\quad$ Regulated energy use $\quad$ Un-regulated energy use

Figure 2 Baseline and reference models results

\section{NZE energy models}

Advanced insulation provides a needed reduction in space heating for the dwellings (also the greatest savings in energy reduction among the advanced energy technologies) in the NZE_red+gen model. One feature that makes the advanced insulation particularly different is that it is an external insulation coated with a highly reflective surface material. According to the current climate weather year data used for simulation, this is not particularly useful and can be disadvantageous during cold periods but is expected to be useful in the future climate to mitigate overheating risk in the UK [12]. Interestingly biPV technology resulted in an overall increase in final energy consumption. Though there was a small increase in generation, the use of biPV as a skylight in the dwelling increased space heating consumption due to loss of roof section which would have had a greater quality of insulation. BiPV could alternatively be used at site level, as examples, on an entry canopy or bus shelter cover; however, in this project this need did not arise. BiPV was not selected for use in the study due to the increase in space heating requirement and preliminary assessment of cost. 
The reduction in regulated energy use by the CHP only considers real time utilisation of the thermal energy by the two case study dwellings based on hourly consumption for each dwelling. The CHP system is however, more effective than it appears if the exported thermal energy not used by the case study dwellings could be utilised by other dwellings in the development, i.e. $100 \%$ of thermal and solar generation by the CHP is usable. The CHP was, however, not selected for the final model in a later optimisation phase as the systems potential would not be maximised in the UK climate. On the other hand, three WindPV systems provided a little over half of the community supplied energy generation needed for the two dwellings. The systems generated an estimated $1809 \mathrm{kWh} / \mathrm{yr}$ per system (911 kWh from solar and $898 \mathrm{kWh}$ from wind). Where roughly another $10 \mathrm{kWh} / \mathrm{m}^{2} / \mathrm{yr}$ per dwelling was needed, PV placed on the energy centre roof was able to supplement the remaining generation need. To summarise, the technologies (in addition to the Baseline+ model) used in the NZE_red+gen model are advanced insulation, WindPV, and additional standard PV on the energy centre of the housing development.

For the next step in the model, NZE_BEMS provides a small reduction in space heating from normal contemporary controls, which allow hourly programming, but is more effective with regard to daylight sensing controls ( $16 \%$ reduction in lighting energy consumption, however, not considered for the target). Figure 3 shows the impact of each technology on the regulated energy and generation for the two dwellings.

Individual NZE red+gen technology performance

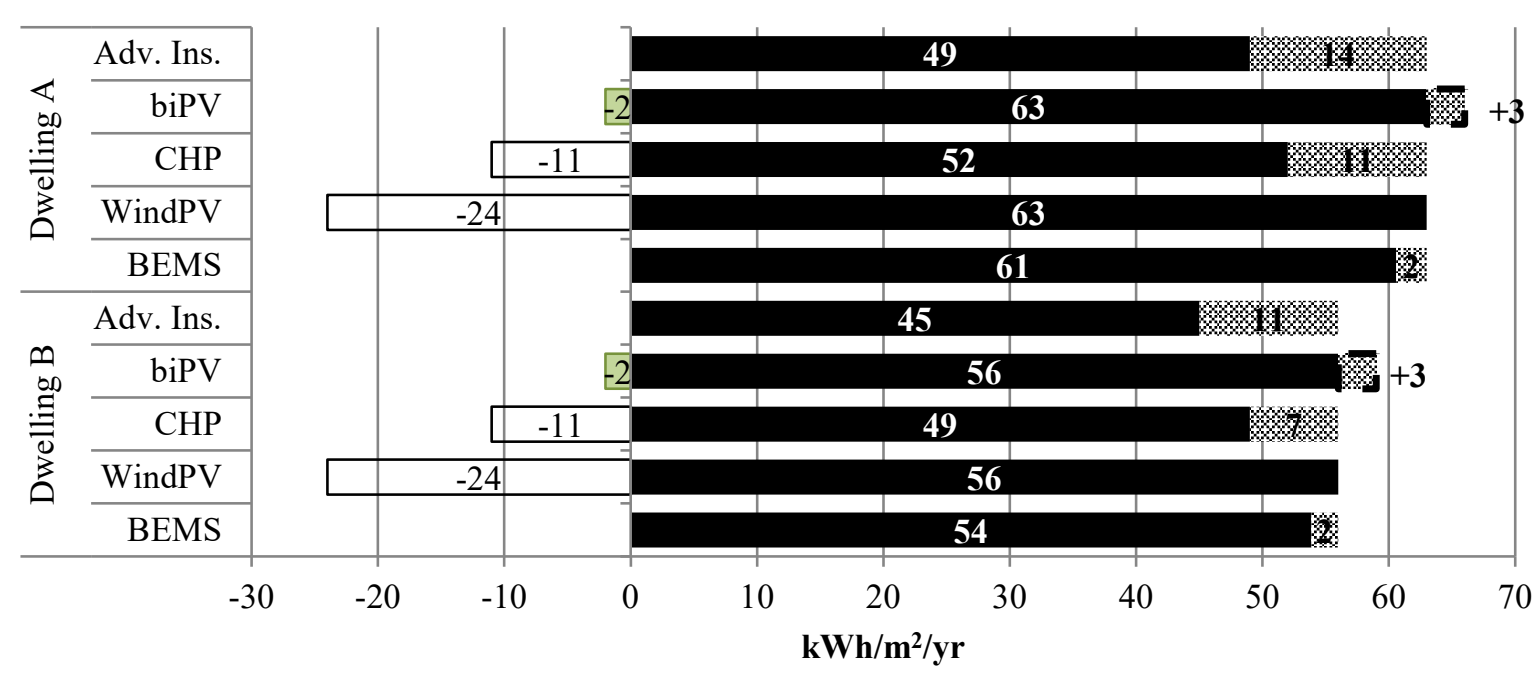

$\square$ Community level RE $\square$ Building level RE $\square$ Regulated energy use $*$ Reduction from Baseline+

Figure 3 Performance of individual energy technologies in the NZE_red+gen models

The findings from the simulation exercises show that the NZE_red+gen version of the case study dwellings achieve the two NZE targets and are potentially plus energy buildings. Table 6 shows the final consumption and generation figures for each modelling phase from the baseline. Figure 4 shows the final design figures for the two dwellings against the design targets (dashed lines) 
Table 6 Final energy figures for the baseline and NZE models

\begin{tabular}{|c|c|c|c|c|}
\hline \multicolumn{5}{|c|}{ DWELLING A $\left(84.4 \mathrm{~m}^{2}\right)$} \\
\hline $\mathrm{kWh} / \mathrm{m}^{2} / \mathrm{yr}$ & Baseline & Baseline+ & NZE red+gen & NZE BEMS \\
\hline Space heating & 36 & 31 & 29 & 27 \\
\hline DHW & 29 & 18 & 18 & 18 \\
\hline Pumps, fans \& ventilation & 2 & 2 & 2 & 2 \\
\hline Regulated energy use & 68 & 51 & 49 & 47 \\
\hline RE & 0 & -20 & -50 & -50 \\
\hline Net regulated energy & 68 & 31 & -1 & -3 \\
\hline \multicolumn{5}{|c|}{ DWELLING B $\left(129.6 \mathrm{~m}^{2}\right)$} \\
\hline $\mathrm{kWh} / \mathrm{m}^{2} / \mathrm{yr}$ & Baseline & Baseline+ & NZE red+gen & NZE BEMS \\
\hline Space heating & 39 & 33 & 31 & 29 \\
\hline DHW & 20 & 12 & 12 & 12 \\
\hline Pumps, fans \& ventilation & 2 & 2 & 2 & 2 \\
\hline Regulated energy use & 61 & 47 & 45 & 43 \\
\hline RE & 0 & -13 & -50 & -50 \\
\hline Net regulated energy & 61 & 34 & -5 & -7 \\
\hline
\end{tabular}

\section{Final net zero modelling figures}

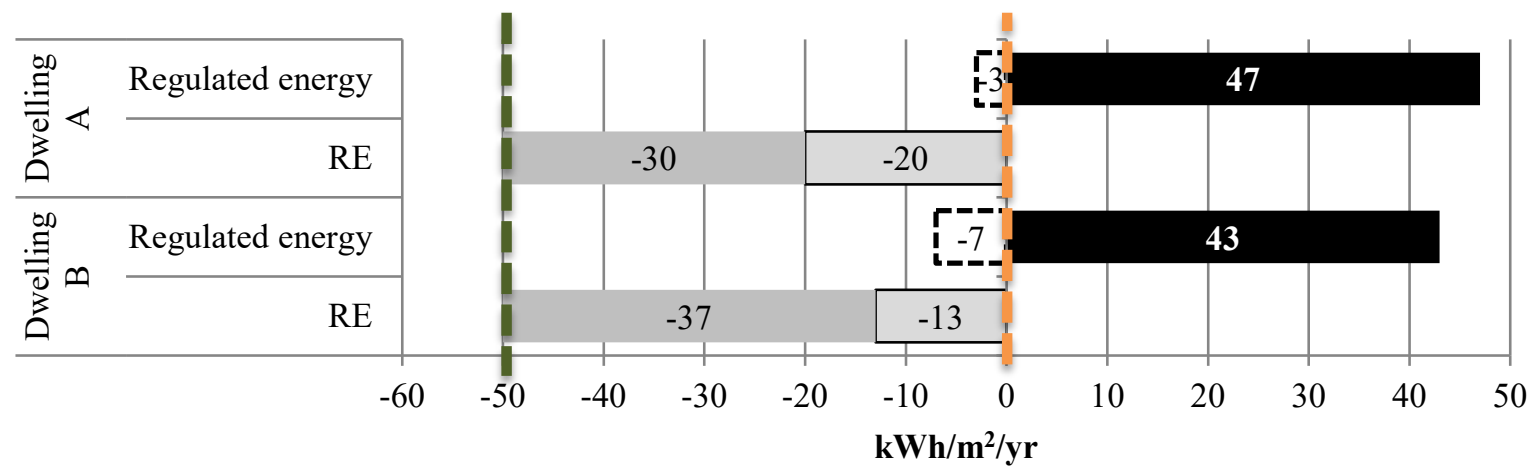

$\square$ Building integrated RE $\backsim$ Community RE $\quad$ \Net regulated energy $\quad$ Regulated energy use

Figure 4 Final net zero energy modelling results for the NZE model

\section{Performance in a warming climate}

Following climate change simulations, table 7 indicates the annual energy use (normalised by dwelling area) for the dwellings. By 2080s both case study dwellings are projected to experience a reduction in regulated energy consumption $\left(11 \mathrm{kWh} / \mathrm{m}^{2} / \mathrm{yr}\right)$ and a small increase in renewable energy generation $\left(2 \mathrm{kWh} / \mathrm{m}^{2} / \mathrm{yr}\right)$. Figure 5 graphically breaks down the energy end use for each climate projection for 2030s, 2050s and 2080s under a high emissions scenario and 50\%. 
Table 7 Annual energy consumption and generation normalised by dwelling area across different climate periods

\begin{tabular}{|l|r|r|r|r|r|r|r|r|}
\hline & \multicolumn{9}{|c|}{ Dwelling A } & \multicolumn{3}{|r|}{ Dwelling B } \\
\hline $\begin{array}{l}\text { Final NZE } \\
\left(\mathrm{kWh} / \mathrm{m}^{2} / \mathrm{yr}\right)\end{array}$ & $\begin{array}{r}\text { Reg. } \\
\text { energy }\end{array}$ & $\begin{array}{r}\text { Total } \\
\text { energy }\end{array}$ & $\begin{array}{r}\text { Energy } \\
\text { prod. }\end{array}$ & Net reg. & $\begin{array}{r}\text { Reg. } \\
\text { energy }\end{array}$ & $\begin{array}{r}\text { Total } \\
\text { energy }\end{array}$ & $\begin{array}{r}\text { Energy } \\
\text { prod. }\end{array}$ & Net reg. \\
\hline $\begin{array}{l}\text { Current } \\
\text { conditions }\end{array}$ & 49 & 98 & -50 & -1 & 45 & 80 & -50 & -5 \\
\hline $\mathbf{2 0 3 0}$ H 50\% & 46 & 95 & -49 & -3 & 41 & 76 & -49 & -8 \\
\hline $\mathbf{2 0 5 0}$ H 50\% & 44 & 93 & -50 & -6 & 39 & 74 & -50 & -11 \\
\hline $\mathbf{2 0 8 0 ~ H ~ 5 0 \% ~}$ & 38 & 87 & -52 & -14 & 34 & 69 & -52 & -18 \\
\hline
\end{tabular}

\section{Climate change scenarios impact on final NZE dwellings}

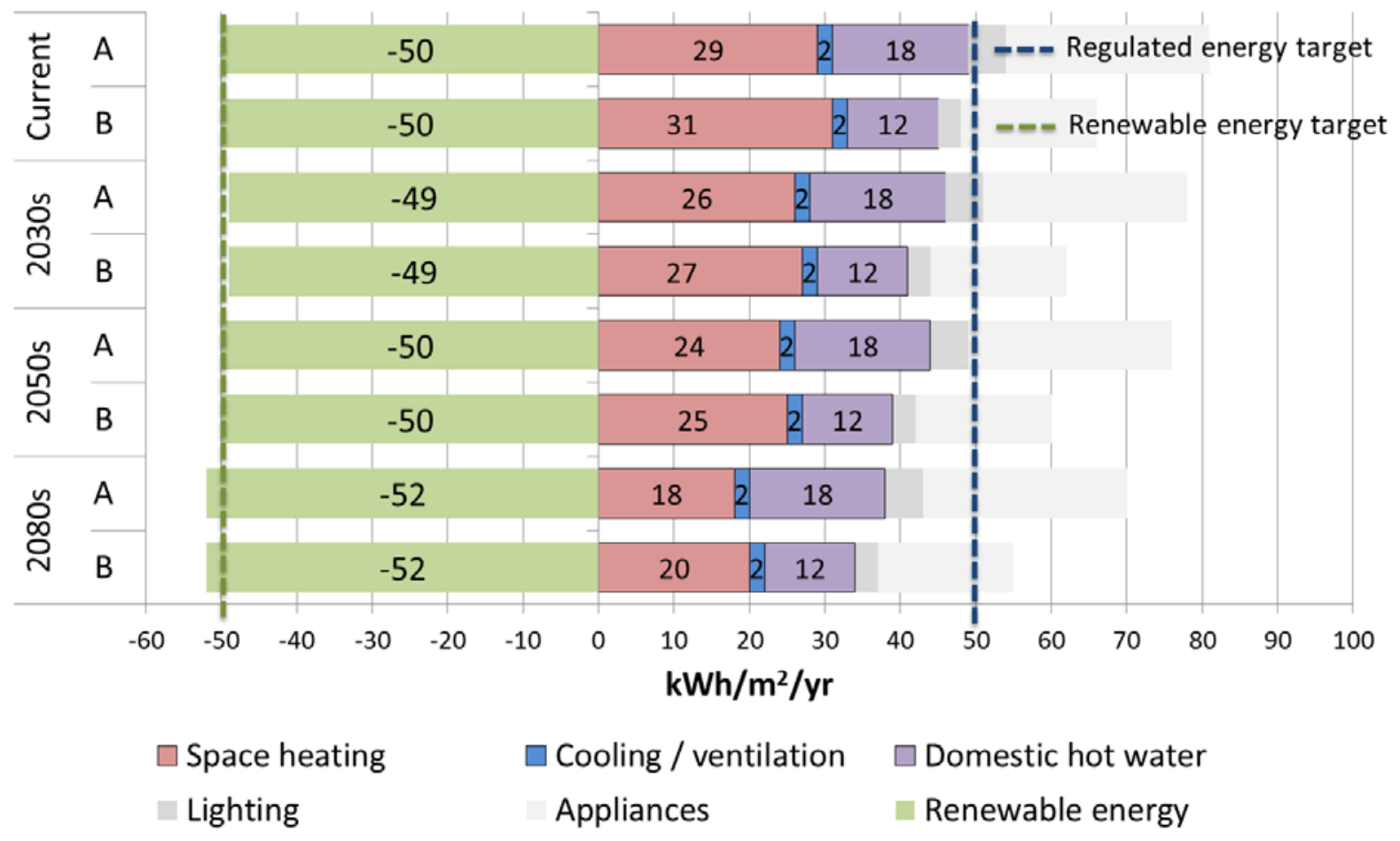

Figure 5 Energy consumption and renewable energy generation results for NZE dwellings under different climate change scenarios

Table 8 shows the overheating results for each criterion using the adaptive comfort method. The results indicate that overheating will likely be a problem for the dwelling by the 2080 s climate period based on current design and construction parameters. Dwelling $A$ also shows some risk of overheating in the living room by the 2050s climate period. As the front facades of the dwellings face northeast, the garden facing aspect of the dwellings face southwest. Common to all designs in the development are large double glass doors in the living room facing the garden and larger windows for other rooms. This could help explain the greater level of overheating in the living room as compared to the bedrooms. Again Bedroom 1 is also southwest facing and overheats a bit more than the second bedrooms. 
Table 8 Simulation based summertime overheating results for the two case study dwellings

\begin{tabular}{|c|c|c|c|c|}
\hline & Criteria 1 & Criteria 2 & Criteria 3 & Criteria failing \\
\hline \multicolumn{5}{|c|}{ Dwelling A } \\
\hline \multicolumn{5}{|c|}{ Current } \\
\hline Living room & 0 & 0 & 0 & - \\
\hline Bedroom 1 & 0 & 0 & 0 & - \\
\hline Bedroom 2 & 0 & 0 & 0 & - \\
\hline \multicolumn{5}{|c|}{2030 H 50\% } \\
\hline Living room & 0 & 0 & 0 & - \\
\hline Bedroom 1 & 0 & 0 & 0 & - \\
\hline Bedroom 2 & 0 & 0 & 0 & - \\
\hline \multicolumn{5}{|c|}{2050 H 50\% } \\
\hline Living room & 9.8 & 21 & 4 & $1 \& 2$ \\
\hline Bedroom 1 & 2.3 & 12 & 2 & 2 \\
\hline Bedroom 2 & 1.2 & 6 & 2 & - \\
\hline \multicolumn{5}{|c|}{2080 H 50\% } \\
\hline Living room & 9.9 & 34 & 5 & $1 \& 2 \& 3$ \\
\hline Bedroom 1 & 8.1 & 27 & 3 & $1 \& 2$ \\
\hline Bedroom 2 & 6.9 & 23 & 4 & $1 \& 2$ \\
\hline \multicolumn{5}{|c|}{ Dwelling B } \\
\hline \multicolumn{5}{|c|}{ Current } \\
\hline Living room & 0 & 0 & 0 & - \\
\hline Bedroom 1 & 0 & 0 & 0 & - \\
\hline Bedroom 2 & 0 & 0 & 0 & - \\
\hline \multicolumn{5}{|c|}{2030 H 50\% } \\
\hline Living room & 0 & 0 & 0 & - \\
\hline Bedroom 1 & 0 & 0 & 0 & - \\
\hline Bedroom 2 & 0 & 0 & 0 & - \\
\hline \multicolumn{5}{|c|}{2050 H 50\% } \\
\hline Living room & 2 & 9 & 2 & 2 \\
\hline Bedroom 1 & 0.2 & 2 & 1 & - \\
\hline Bedroom 2 & 0.6 & 3 & 2 & - \\
\hline \multicolumn{5}{|c|}{2080 H $50 \%$} \\
\hline Living room & 7.8 & 19 & 3 & $1 \& 2$ \\
\hline Bedroom 1 & 5.6 & 15 & 2 & $1 \& 2$ \\
\hline Bedroom 2 & 3.8 & 13 & 4 & $1 \& 2$ \\
\hline
\end{tabular}

\section{Discussion}

The NZE design satisfies the three EU 2020 targets and achieve long-term UK climate change target of $\mathrm{CO}_{2}$ emissions reduction by $80 \%$. In detail, this means that as compared to the baseline model (designed to surpass 1990 levels):

- The reduction in total energy consumption (not including generation) resulted in a $\mathrm{CO}_{2}$ emissions reduction of $37 \%$ for Dwelling A and 35\% for Dwelling B (emission factors [33]). This satisfies 'reduce greenhouse gas emissions by $20 \%$ ';

- The reduction in total energy consumption resulted in an energy efficiency increase of $35 \%$ for Dwelling A and 33\% for Dwelling B. Regulated energy consumption alone resulted in an 
energy efficiency increase of $31 \%$ for Dwelling A and $30 \%$ for Dwelling B. Either condition satisfies 'increase energy efficiency by $20 \%$ '; and

- The contribution from renewables is equivalent to total final energy consumption of $62 \%$ for Dwelling A and $77 \%$ for Dwelling B. This satisfies the criteria of 'increase contribution from renewable energy sources equivalent to $20 \%$ of final energy consumption.'

The findings above reveal that to meet the specific targets set out for the study aligned with the EU Directive:

- A majority of technological intervention must come from community renewables, as the dwellings themselves could not spatially support the necessary generation requirement on the roof;

- Dwellings built to current UK Building Regulations will need to reduce regulated loads by a little over one-half; and

- Though the modelled dwellings resulted in greater reductions than necessary, the NZE targets in particular are not as stringent regarding energy efficiency but are highly expectant with regard to renewable energy.

In a housing development like the one in this case study with a devoted energy centre, community renewables contribution made the task easier to achieve. The study also supports the findings in Kapsalaki and Leal [3] which examined the success of dwellings designed to be NZE in a number of countries. Many of the dwellings were able to achieve the NZE title; furthermore, it was found that combining standard design with a sufficient offset of on-site renewables often made the goal practically achievable. The positive aspect of combining the NZE approach with the EU 2020 targets is to ensure level reductions throughout, covering efficiency and emissions, rather than simply covering all consumption with renewables.

Design had a heavy influence on tackling the risk of summertime overheating, and given the prevalence of overheating in new, retrofitted and high-performing dwellings in the current climate $[16,34,35]$, adaptive measures would definitely have their place in current new-build. The advanced insulation technology selected for the project had a highly reflective surface for reducing the impact of solar gain on the opaque wall surface. It is expected that this technology will benefit the dwellings as the climate warms. It does appear; however, that further implementation of passive measures would be useful beyond the 2050s climate period. Passive design strategies such as designed-in seasonal shading and light coloured surfaces evaluated elsewhere $[13,14,36]$, continually prove effective. It is also suggested that during a retrofit, potentially in thirty years that shading be used on the dwellings. This approach has been explored in [37] where packages are phased in over changing climate periods to consider the impact of the packages on the dwellings' energy performance and indoor temperatures. It is also vital to engage with future occupants about managing heat during hot weather; occupant behaviour is highly important when affecting the level of overheating [35].

\section{Conclusion}

The paper has demonstrated a systematic approach to meeting UK and EU targets outlined in the introduction and discussion. Essentially, not only is it easier to meet these targets, particularly those regarding renewables, by integrating community scale renewables but it is also beneficial to meet 
targets on a community scale with regard to overall efficiency of implementation, utilisation of renewable energy, and economy of scale. The paper further explored the impact of a changing climate in the UK on the energy efficiency and generation of the improved dwellings and the overheating risk potential. Overall by the 2080s, both dwellings are projected to experience a reduction in regulated energy consumption and a small increase in renewable energy generation. Overheating risk has been shown to increase from none in the current climate to overheating in all rooms in both dwellings by the 2080s.

Suggested further work will include monitoring of the performance of the advanced energy technologies, which will be undertaken as part of the wider Horizon 2020 project. With the advancement of BEMS technology there is integration of more detailed management of energy consumption, e.g. smart phone control of BEMS and geolocation alerts. Evaluation of the impact of BEMS with these features would require monitoring due to the complex nature of actual use and change in daily patterns. In addition, monitoring of the risk of overheating (through indoor and outdoor temperatures) in the current climate would also be of interest, especially when considering the change made to the fabric and whether adaptation needs to be coupled with the approaches taken to reduce energy consumption.

\section{Acknowledgement}

The research study is part of the Zero Plus research project, which has received funding from the European Union's Horizon 2020 Research and Innovation programme under Grant Agreement No. 678407. The authors would also like to thank the developer and architect of the case study dwellings.

\section{References}

[1] EC, Europe 2020 targets, in: Europe 2020, European Commission, 2015.

[2] E. Recast, Directive 2010/31/EU of the European Parliament and of the Council of 19 May 2010 on the energy performance of buildings (recast), Official Journal of the European Union, 18 (06) (2010) 2010.

[3] M. Kapsalaki, V. Leal, Recent progress on net zero energy buildings, Advances in Building Energy Research, 5 (1) (2011) 129-162.

[4] J.M. Murphy, D. Sexton, G. Jenkins, B. Booth, C. Brown, R. Clark, M. Collins, G. Harris, E. Kendon, R. Betts, UK climate projections science report: climate change projections, (2009).

[5] W. Stahl, K. Voss, A. Goetzberger, The self-sufficient solar house in Freiburg, Solar Energy, 52 (1) (1994) 111-125.

[6] B. Vale, R.J.D. Vale, The new autonomous house: Design and planning for sustainability, Thames \& Hudson, 2000.

[7] A.-F. Marique, S. Reiter, A simplified framework to assess the feasibility of zero-energy at the neighbourhood/community scale, Energy and Buildings, 82 (2014) 114-122.

[8] K. Voss, E. Musall, M. Lichtmeß, From low-energy to Net Zero-Energy Buildings: status and perspectives, Journal of Green building, 6 (1) (2011) 46-57.

[9] N. Malin, The Problem with Net-Zero Buildings (and the Case for Net-Zero Neighborhoods), Environmental building news, 19 (8) (2010) 1-15.

[10] S.A. Halasah, D. Pearlmutter, D. Feuermann, Field installation versus local integration of photovoltaic systems and their effect on energy evaluation metrics, Energy policy, 52 (2013) 462471. 
[11] R. Gupta, M. Kapsali, Empirical assessment of indoor air quality and overheating in low-carbon social housing dwellings in England, UK, Advances in Building Energy Research, 10 (1), (2015) 46-68. [12] R. Gupta, M. Gregg, Using UK climate change projections to adapt existing English homes for a warming climate, Building and Environment, 55 (September) (2012) 20-42.

[13] R. Gupta, M. Gregg, Preventing the overheating of English suburban homes in a warming climate, Building Research \& Information, 41 (3) (2013) 281-300.

[14] R.S. McLeod, C.J. Hopfe, A. Kwan, An investigation into future performance and overheating risks in Passivhaus dwellings, Building and Environment, 70 (December) (2013) 189-209.

[15] A. Simone, M. AVANTAGGIAT, M. De Carli, B.W. Olesen, Effect of passive cooling strategies on overheating in low energy residential buildings for Danish climate, in: 8th Windsor Conference: counting the cost of Comfort in a changing world, 2014, pp. 10-13.

[16] S.M.T. Sameni, M. Gaterell, A. Montazami, A. Ahmed, Overheating investigation in UK social housing flats built to the Passivhaus standard, Building and Environment, 92 (October) (2015) 222235.

[17] T.S. Larsen, R.L. Jensen, Comparison of measured and calculated values for the indoor environment in one of the first Danish passive houses, in: 12th Conference of International Building Performance Simulation Association, Sydney, 2011, pp. 1414-1421.

[18] S.H. Ruud, L. Lundin, M. Sandberg, J. Nielsen, A. Wahlström, T. Törnström, P. Kovacs, Houses without a traditional heating system-results from two years of measurement, in: World Sustainable Building Conference, Tokyo, Tokyo, 2005, pp. 1143-1150.

[19] M. Maivel, J. Kurnitski, T. Kalamees, Field survey of overheating problems in Estonian apartment buildings, Architectural Science Review, 58 (1) (2015) 1-10.

[20] M. Orme, J. Palmer, S. Irving, Control of overheating in well-insulated housing, in: Proceedings of the CIBSE/ASHRAE Conference (24-26 September 2003) in Building Sustainability, Value \& Profit, Edinburgh, 2003.

[21] R. Gupta, M. Gregg, Empirical evaluation of the energy and environmental performance of a sustainably-designed but under-utilised institutional building in the UK, Energy and Buildings, 128 (2016) 68-80.

[22] A.-A. Tillson, T. Oreszczyn, J. Palmer, Assessing impacts of summertime overheating: Some adaptation strategies, Building Research \& Information, 41 (6) (2013) 652-661.

[23] E. Oikonomou, M. Davies, A. Mavrogianni, P. Biddulph, P. Wilkinson, M. Kolokotroni, Modelling the relative importance of the urban heat island and the thermal quality of dwellings for overheating in London, Building and Environment, 57 (2012) 223-238.

[24] S. Berry, D. Whaley, K. Davidson, W. Saman, Near zero energy homes-What do users think?, Energy Policy, 73 (2014) 127-137.

[25] J. Schnieders, Passiv houses in South West Europe: a quantitative investigation of some passive and active space conditioning techniques for highly energy efficient dwellings in the South West European region, Passivhaus Inst., 2009.

[26] M. Eames, T. Kershaw, D. Coley, On the creation of future probabilistic design weather years from UKCP09, Building Services Engineering Research and Technology, 32 (2) (2011) 127-142.

[27] F. Nicol, B. Spires, The limits of thermal comfort: avoiding overheating in European buildings: CIBSE TM52: 2013, The Chartered Institution of Building Services Engineers, London, 2013.

[28] DCLG, English Housing Survey: Profile of English housing: Annual report on England's housing stock, 2013, in: D.f.C.a.L. Government (Ed.), Department for Communities and Local Government, London, 2015, pp. 105.

[29] BRE, Building Typology Brochure England: September 2014 in, Building Research Establishment, Watford, 2014, pp. 40.

[30] H. Government, The building regulations 2010: Approved document L1A Conservation of fuel and power in new dwellings, in: Approved document L1A Conservation of fuel and power in new dwellings, NBS, London, 2014, pp. 48. 
[31] S. Deng, R. Wang, Y. Dai, How to evaluate performance of net zero energy building-A literature research, Energy, 71 (2014) 1-16.

[32] E. Musall, T. Weiss, A. Lenoir, K. Voss, F. Garde, M. Donn, Net Zero energy solar buildings: an overview and analysis on worldwide building projects, in: EuroSun conference, 2010.

[33] BRE, The Government's Standard Assessment Procedure for Energy Rating of Dwellings: 2012 edition, in: E.a.I.S. Department for Business (Ed.), Building Research Establishment, Watford, 2014, pp. 232.

[34] R. Gupta, M. Kapsali, Evaluating the effect of occupant behaviour and expectations on actual energy use and environmental conditions in 'sustainable'social housing in South East England, in: Windsor Conference, Cumberland Lodge, Windsor, UK, 2014, pp. 1-25.

[35] A. Dengel, M. Swainson, Overheating in new homes: A review of the evidence, Research Review, Zero Carbon Hub, (2012).

[36] S.M. Porritt, P.C. Cropper, L. Shao, C.I. Goodier, Ranking of interventions to reduce dwelling overheating during heat waves, Energy and Buildings, 55 (2012) 16-27.

[37] R. Gupta, M. Gregg, Adapting UK suburban homes for a warming climate, in: Windsor Conference, Network for Comfort and Energy Use in Buildings, Cumberland Lodge, Windsor, UK, 2012.

i The Code for Sustainable Homes (CSH) is the national standard for the sustainable design and construction of new homes. It aims to reduce carbon emissions and promote higher standards of sustainable design above the current minimum standards set out by the building regulations. Until March 2015, the code could be mandatory in England, Wales and Northern Ireland if it was a requirement of a local authority's local plan, or where affordable housing was funded by the Homes and Community Agency. The Code is still operational, but is now generally voluntary. 